\title{
Wine of Cool-climate Areas in South Poland
}

\author{
J. Dobrowolska-Iwanek ${ }^{1 *}$, M. Gąstoł², A. Wanat ${ }^{1}$, M. Krośniak ${ }^{1}$, M. Jancik ${ }^{1}$, P. Zagrodzki ${ }^{1,3}$
}

(1) Department of Food Chemistry and Nutrition, Faculty of Pharmacy, Medical College Jagiellonian University, Medyczna 9, 30-688 Krakow, Poland

(2) Department of Pomology and Apiculture, Agricultural University, 29 Listopada 54, 31-425 Krakow, Poland

(3) Henryk Niewodniczański Institute of Nuclear Physics, Polish Academy of Sciences, Krakow, Poland

Submitted for publication: May 2013

Accepted for publication: October 2013

Key words: Grape cultivars, food composition, antioxidant activity, polyphenols, organic acids

\begin{abstract}
A number of new vinery production regions, especially in the southern parts of Poland, have appeared in the last ten-odd years. This study was aimed at completing the chemical characterisation of wine produced from ten Polish grape cultivars planted near Krakow. The wine was analysed to determine organic acid concentrations, total polyphenols and extract content, antioxidant activity, alcohol content, total acidity and pH. Moreover, a sensory analysis was performed on the wine. Significant differences were recorded between red and white wine. The total acidity expressed as tartaric acid, and tartaric and malic acid concentrations, were significantly higher in white and red wines, whereas antioxidant activity and phenolic content were significantly higher in the red wines. Similarities and relationships between various parameters and specific wine brands were further examined with cluster analysis. Our results show that, under Polish climatic conditions, it is possible to produce wine with quality comparable to wine from established wine denomination regions. Selected wine brands showed high antioxidant activity (FRAP - ferric reducing antioxidant power) and a high level of polyphenols. This study also provides confirmation that wines from colder climates frequently reveal unique and desirable properties.
\end{abstract}

\section{INTRODUCTION}

Wine as a beverage has been known for over 8000 years (Pellechia, 2006). From the beginning of Polish state history, specifically following the official birth of the country in 966 , wine was frequently used as an important element of the Christian culture. Once Christianity was adopted, the first wines were imported from Hungary, France, Italy and Crete. However, they were very expensive and the vineyards owned by Christian monasteries soon became the main source of wine in Poland. The first vineyards were established in the vicinity of Kraków, then Poland's capital (Kosmaczewska, 2008). Further significant cultural development took place within Polish territory in the $14^{\text {th }}$ and $15^{\text {th }}$ century, which was followed by a peak in wine production. Later, in parallel to the political muddle and civil wars of the Middle Ages, wine production declined to a practically non-existent level until the end of $20^{\text {th }}$ century. This period was also associated with climatic changes in Europe, such as the Little Ice Age from 1350 to 1850 , which caused grapes to freeze and led to their irreversible damage (Estreicher, 2004; Yiou et al., 2012). In addition, the policy of the three states that partitioned Poland (1772 to 1918) did not favour winegrowing or winemaking. After World War II, i.e. over the period of communism in Poland (1945 to 1989), good quality wine was considered an exclusive product, thus its production was not allowed. It was not until 1989 that the situation changed. The economic development of Poland and growing interest in studying oenology, associated with a wide appreciation of the beneficial effects of grapes and wine on human health, supported by the observed climate warming, have opened new opportunities for growing and producing good quality wine.

Nowadays, we see a real renaissance of Vitis sp. cultivation. Approximately 200000 new vines are planted annually (Lisek, 2002). New vinery production regions have appeared in the warmer regions of Poland. It is a wellknown fact that severe environmental factors, making the plant stressed, stimulate the production and accumulation of secondary metabolites (Myśliwiec, 2009). Therefore, wine produced in colder climatic zones often reveal unique properties. As the climatic conditions in Poland are still too severe for Vitis vinifera vines, most of the planted vineyards are composed of crosses between $V$. vinifera and native North America species (French hybrids), with higher resistance to cold and pests (Winkler et al., 1974). For wine produced from such cultivars, both the taste and chemical compound content are different when compared with $V$. vinifera varieties.

Apart from the cultivar type, the chemical composition of grapes depends mainly on the geographic location, soil type, environmental and climatic conditions, plant diseases, 
and vintage (Mulero et al., 2011). Organic acids and phenolic compounds are among the major components of grape berries.

Organic acids play an important role in the winemaking process. They determine not only the organoleptic qualities of the wine, such as taste, aroma and colour, but also the physical and biochemical properties, as well as the microbial stability of the wine (Volschenk et al., 2006). Moreover, organic acids have an influence on human health and may play a protective role against various diseases due to their antioxidant activity (Silva et al., 2004). The organic acid composition of wine depends on the profile of such compounds in the grapes used in wine production, as well as on the winemaking and ageing process (Jackson, 2008). The major grape acids are tartaric and malic acid. The tartaric acid content in grapes gradually increases with ripening, whereas the malic acid content tends to decrease (Saito \& Kasai, 1968; Garrido-Delgado et al., 2009). Citric acid is less abundant in grapes, but similarly to malic acid it is easily degraded by lactic bacteria. Lactic acid is formed mainly in the process of malolactic fermentation by lactic acid bacteria, or it can be synthesised by yeast (Volschenk et al., 2006). Acetic acid can be produced by bacteria, namely acetic bacteria, but small amounts are also formed during fermentation. Succinic acid is the major acid produced by yeast during sugar fermentation (GarridoDelgado et al., 2009).

Beside organic acids, phenolic compounds are also important with regard to the colour, sensory attributes and antioxidant properties of wine. The main polyphenolic components have been classified into several classes, namely hydroxycinnamic and hydroxybenzoic acids, anthocyanins, flavonols, flavanols, stilbenes and tannins. Wine phenolic composition depends on the grapes from which they are partly extracted, and on the vinification conditions (Aznar et al., 2011).

The work presented here was aimed at evaluating the concentrations of organic acids, total polyphenols and extract content, antioxidant activity, alcohol content, total acidity, $\mathrm{pH}$ and sensory characteristics of red and white wines produced from different grape cultivars grown in Southern Poland.

\section{MATERIALS AND METHODS \\ Chemicals}

Deionised water at $18 \mathrm{M} \Omega \mathrm{cm}$ was obtained from the MilliRO and -Q water purification system. Acetic acid, 36\% hydrochloric acid, caproic acid and $1 \mathrm{~g} / \mathrm{L}$ of ferric chloride $\left(\mathrm{FeCl}_{3}\right)$ were purchased from Fluka (Steinheim, Germany); triphenyltiazine (TPTZ)-2,4,6-tris (2pyridyl)-1,3,5-triazine and gallic acid were purchased from Sigma-Aldrich Chemie GmbH (Steinheim, Germany), Folin-Ciocalteu reagent from Fluka (Steinheim, Germany), malic acid and succinic acid from Lancaster (Morecambe, England), M-HEC from HERCULES (Prague, Czech Republic), $\beta$-alanine from LACHEMA (Brno, Czech Republic), L-histidine from Serva (Heidelberg, Germany), and sodium carbonate $\left(\mathrm{Na}_{2} \mathrm{CO}_{3}\right)$, tartaric acid and $80 \%$ lactic acid from POCh (Gliwice, Poland). All the chemicals were of analytical purity.

\section{Grapes}

Grapes were harvested in the 'Garlicki Lamus' vineyard located at the Experimental Research Station Garlica Murowana, near Krakow. The cultivars used for this experiment are listed in Table 1. Three batches, each containing $100 \mathrm{~kg}$ of grapes, were used to produce the wine.

\section{Winemaking \\ Red wines}

Once the grapes had been destemmed and crushed (Griffo DMCSI crusher, GRIFO Macchine Enologiche, Italy), potassium metabisulphite (14 g/100 kg of grapes) was added. All the musts were inoculated with dry active yeast $(30 \mathrm{~g} / \mathrm{hL}$ Saccharomyces cerevisiae, Lalvin RA 17; Lalvin, Canada). The fermentation, at a temperature of 22 to $24^{\circ} \mathrm{C}$, lasted 10 days. At devatting, free-run juice was obtained and the marc was pressed with a stainless steel manual press. In all cases,

TABLE 1

Grape cultivars used in this experiment (in alphabetical order).

\begin{tabular}{|c|c|c|c|c|}
\hline Name & Synonyms & Derivation & Origin & Grape colour \\
\hline Aurora & Seibel 5279 & Seibel $788 \times$ Seibel 29 & France & white \\
\hline Bianca & $\begin{array}{l}\text { E.Cs.40, } \\
\text { Egri Csillagok } 40, \\
\text { Bianka }\end{array}$ & Seyve Villard $12375 \times$ Bouvier & Hungary & white \\
\hline Jutrzenka & - & Seyve Villard 12-375 $\times$ Pinot Blanc & Poland & white \\
\hline Muskat Odesskij & - & Muskat Sinij Ranij $\times$ Seyve Villard 20-366 & Ukraine & white \\
\hline Seyval Blanc & Seyve Villard 5-276 & Seibel $4995 \times$ Seibel 4986 & France & white \\
\hline Sibera & Gm 6495-3 & $\begin{array}{l}\text { Saperawi siewiernyj } \times \text { Foster White } \\
\text { Seedling } \times \text { Prachtraube }\end{array}$ & Germany & white \\
\hline Leon Millot & $\begin{array}{l}\text { Kuhlmann } \\
194-2\end{array}$ & MgT101-14 × Goldriesling & France & red \\
\hline Marechal Foch & Kuhlmann 188-2 & MgT101-14 × Goldriesling & France & red \\
\hline Regent & $\begin{array}{l}\text { Geilweilerhof } \\
67-198-3\end{array}$ & $\begin{array}{l}\text { Sylvaner } \times \text { Müller } \\
\text { Thurgau } \times \text { Chambourcin }\end{array}$ & Germany & red \\
\hline Rondo & Gm 6494-5 & Saperawi Siewiernyj $\times$ Saint Laurent & Germany & red \\
\hline
\end{tabular}


free-run juices and press juices were mixed. The wines were kept in stainless steel tanks where fermentation was completed until racking. At the end of alcoholic fermentation, dioxide additions $(50 \mathrm{mg} \mathrm{SO} / \mathrm{L})$ were introduced to inhibit malolactic fermentation. Once racked, the wines were kept in $25 \mathrm{~L}$ glass containers under argon and closed with corks until analysis.

\section{White wines}

Potassium metabisulphite ( $4 \mathrm{~g}$ to $100 \mathrm{~kg}$ of grapes) was added prior to crushing. Short maceration was applied only for Jutrzenka ( 3 to $4 \mathrm{~h}, 4^{\circ} \mathrm{C}$ ). Juices were obtained with a vertical hydraulic press (Cabbia D/70, Italy). All the musts were inoculated with dry active yeast $(20 \mathrm{~g} / \mathrm{hL}$ Saccharomyces cerevisiae, strain D 576; Begerow, Germany). The fermentation temperature ranged between 20 and $22^{\circ} \mathrm{C}$. The wines were kept in stainless steel tanks (Lavinox, Slovenia) until fermentation was completed. Afterwards the wines were kept in $25 \mathrm{~L}$ glass containers under argon and closed with corks until analysis.

\section{Sample preparation}

Each sample of the investigated wine was centrifuged at $3000 \mathrm{rpm}$ for $15 \mathrm{~min}$ and diluted with deionised water. Each measurement of the subsequent parameters was repeated three times and the result was expressed as the mean value $\pm \mathrm{SD}$.

\section{Determination of organic acids}

Isotachophoretic separation was performed with the Electrophoretic Analyser EA 202M (Villa Labeco, Spisska Nova Ves, Slovakia) with conductivity detection. The system was equipped with a sample valve of $30 \mu \mathrm{m}$ fixed volume, a pre-separation (90 $\mathrm{mm} \times 0.9 \mathrm{~mm}$ I.D.) and an alytical capillary (160 mm x $0.3 \mathrm{~mm}$ I.D.). The leading electrolyte was hydrochloric acid solution $(10 \mathrm{mM})$, including $0.2 \%$ methylhydroxyethylcellulose (M-HEC) adjusted with $\beta$-alanine to $\mathrm{pH}$ 3.5. The terminating electrolyte contained $5 \mathrm{mM}$ of caproic acid and $5 \mathrm{mM}$ of histidine.

\section{Determination of total phenolics}

The total phenolic compounds (TPC) of the wine samples were assessed by means of the Follin-Ciocalteu reagent method. A slightly modified analytical procedure, reported earlier (Paśko et al., 2009), was performed. An amount of $540 \mu \mathrm{L}$ of deionised water was mixed with $60 \mu \mathrm{L}$ of sample, $60 \mu \mathrm{L}$ of $7 \%$ (w/w) $\mathrm{Na}_{2} \mathrm{CO}_{3}$ and $30 \mu \mathrm{L}$ of Follin-Ciocalteu solution. The mixture of water and the reagents was used as a blank. The absorbance was measured with a Synergy 2 Multi-Mode Microplate reader spectrophotometer from BioTek Instruments at $725 \mathrm{~nm}$. The total phenol content was determined using the standard gallic acid (GA) calibration curve ( 0.05 to $0.30 \mathrm{~g} / \mathrm{L} \mathrm{GA})$. The final results were expressed as GA equivalents.

\section{Determination of extract in wine}

A refractometric method was used for extract determination. A drop of each wine was applied to the refractometer (Atago PR 100).

\section{Determination of FRAP activity}

The FRAP assay was performed according to Benzie's method (Benzie \& Strain, 1996), with modifications as described by Paśko et al. (2009). The method is based on the sample-reducing power measurement with the Fe(III) tripyridyltriazine complex. FRAP analysis was performed at $37^{\circ} \mathrm{C}$ and a $\mathrm{pH}$ of 3.6. Ferric tripyridyltriazine (Fe(III)TPTZ) complex reduction of the blue-coloured ferrous tripyridyltriazine (Fe(II)-TPTZ) was monitored by measuring the absorption change at $593 \mathrm{~nm}$ using a Synergy 2 MultiMode Microplate reader spectrophotometer from BioTek Instruments. Absorbance was proportional to the antioxidant capacity of the antioxidants in the samples, determined after $30 \mathrm{~min}$. The standard curve was linear within the range 0.25 to $1.50 \mathrm{mmol} / \mathrm{L} \mathrm{FeSO}_{4} \cdot \mathrm{H}_{2} \mathrm{O}$. The final results are given as $\mathrm{mmol} \mathrm{Fe} \mathrm{F}^{2+} / \mathrm{L}$.

\section{Total acidity}

The determination of total acidity was carried out by means of the OIV-MA-AS313-01: R2009 method described in the Compendium of International Methods of Analysis (Organisation Internationale de la Vigne et du Vin, "OIV”).

\section{Analysis of $\mathbf{p H}$}

The acidity of specific samples was determined with an Elmetron CP-505 pH meter (Elmetron Sp.j, Zabrze, Poland).

\section{Alcoholic strength}

Measurement of the distillate alcoholic strength was performed with a pycnometer according to the OIVMA-AS312-01A method (Method A2/1978 - Resolution 377/2009), described in the Compendium of International Methods of Analysis (Organisation Internationale de la Vigne et du Vin, n.d.).

\section{Sensory analysis}

A sensory evaluation was performed by a certified assessor in compliance with the WSET SAT (Systematic Approach to Tasting) 2012 standards.

\section{Statistical analysis}

The statistical analysis was performed by means of a nonparametric Mann-Whitney U test. The level of significance was set at $p<0.05$. Correlations between parameters were evaluated by calculating Spearman correlation coefficients. The similarities and relationships between various parameters and the specific objects (wine brands) were examined by Ward's method of clustering and Euclidean distance. In order to eliminate the influence of original units, all parameters were standardised before cluster analysis by subtracting the mean value and dividing it by standard deviation to obtain mean value equal to zero and standard deviation equal to one.

The results of the cluster analysis are shown as dendrograms. All calculations were performed using Statistica 10 software (StatSoft, Inc., Tulsa, USA). 


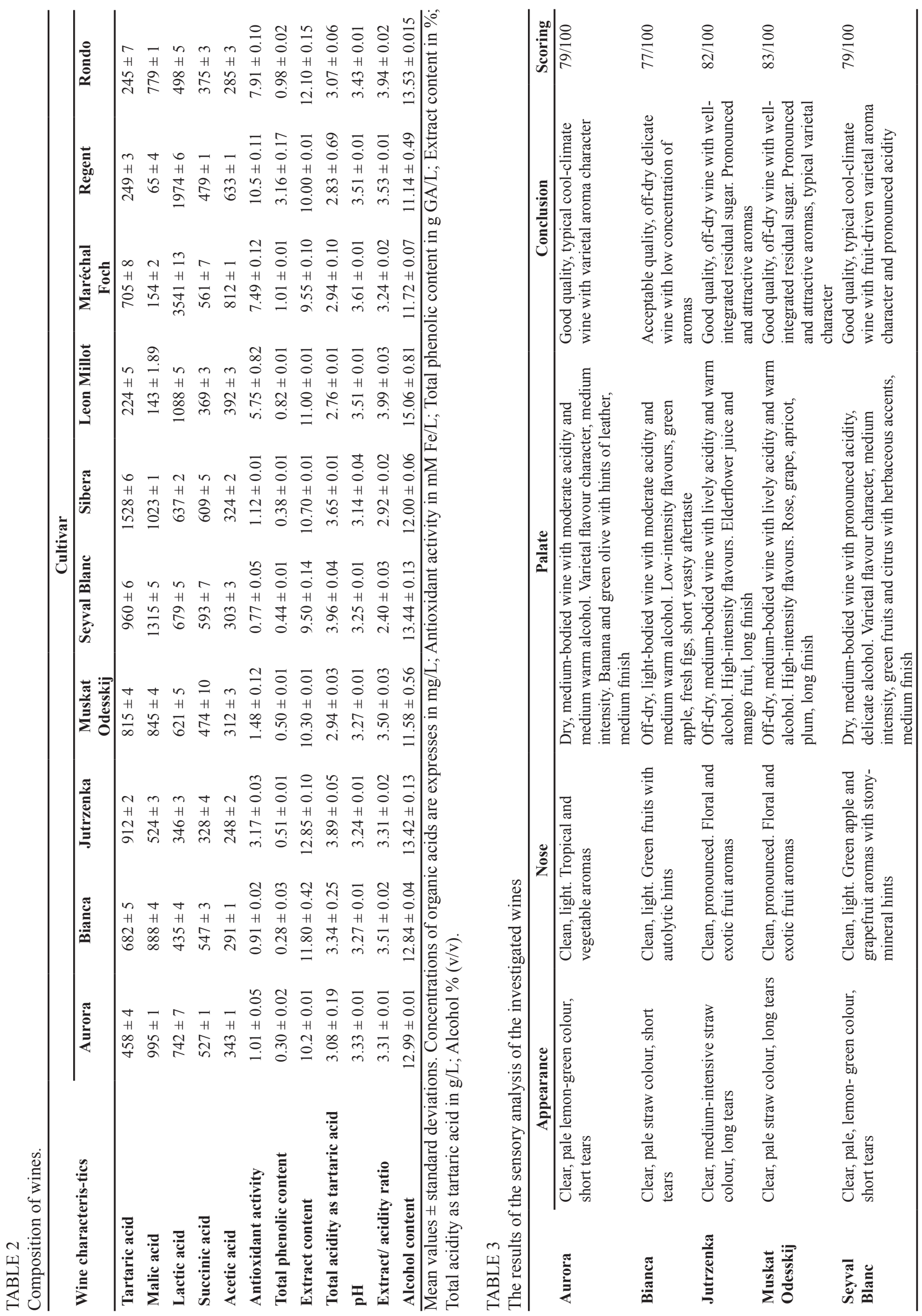


The composition of the analysed wines and the results of the sensory analysis are presented in Tables 2 and 3, respectively.

\section{Organic acids}

Electrophoresis made it possible to separate and identify five organic acids in the wine samples, namely tartaric, malic, lactic, succinic and acetic acid.

The tartaric acid content varied from $224 \pm 5$ to $705 \pm$ $8 \mathrm{mg} / \mathrm{L}$ and from $458 \pm 4$ to $1528 \pm 6 \mathrm{mg} / \mathrm{L}$ for the red and white wine respectively (Fig. 1). The highest tartaric acid concentration for white wine was determined in Sibera wine, whereas for the red wine group it was in Maréchal Foch wine. The lowest amounts were observed in Aurora and Leon Millot. The difference in tartaric acid concentration in the red and white wine was statistically significant $(p=0.033)$.

The malic acid concentration in the majority of the examined white wines was significantly higher than in the red wine ( $p=0.02$; Fig. 2 ). The highest amount of malic acid was observed in Rondo $(779 \pm 1 \mathrm{mg} / \mathrm{L})$ as far as the red wine was concerned, whereas for the white wine it was in Seyval Blanc (1 $315 \pm 5 \mathrm{mg} / \mathrm{L})$. The lowest malic acid content was determined in Jutrzenka white wine $(524 \pm 3 \mathrm{mg} / \mathrm{L})$ and Regent red wine $(65 \pm 4 \mathrm{mg} / \mathrm{L})$.

The lactic acid concentration in the red wine varied considerably, from the $498 \pm 5 \mathrm{mg} / \mathrm{L}$ observed in Rondo to $3541 \pm 13 \mathrm{mg} / \mathrm{L}$ in Maréchal Foch. In general, the concentrations of this acid were lower for white than for red wine, and varied from $346 \pm 3 \mathrm{mg} / \mathrm{L}$ to $742 \pm 7 \mathrm{mg} / \mathrm{L}$ for Jutrzenka and Aurora, although the difference between these two groups of wine was insignificant.

The concentrations of succinic acid in the analysed samples fell within a narrower range compared to the other organic acids. The determined range for the red and the white wine was $369 \pm 3 \mathrm{mg} / \mathrm{L}$ to $561 \pm 7 \mathrm{mg} / \mathrm{L}$ and $328 \pm 4 \mathrm{mg} / \mathrm{L}$ to $609 \pm 5 \mathrm{mg} / \mathrm{L}$, respectively. There were no significant differences between the succinic acid concentrations in the red and white wine. The highest succinic acid concentration for red wine was found in Maréchal Foch, while the lowest was in Leon Millot. Within the white wine group, its highest level was observed in Sibera, while the lowest was in Jutrzenka.

The concentrations of acetic acid in the white wine (248 \pm 2 to $343 \pm 1 \mathrm{mg} / \mathrm{L}$ ) were in most cases lower than in the red wine $(285 \pm 3$ to $812 \pm 1 \mathrm{mg} / \mathrm{L})$, but the difference was not significant. The highest concentrations were found in red Maréchal Foch and white Aurora, while the lowest were found in red Rondo and white Jutrzenka.

\section{FRAP and total phenolic content}

Antioxidant activity and phenolic content were significantly higher (both: $p=0.011$ ) for red wine when compared with the white wine (Figs 3 and 4). Moreover, the statistical analysis revealed a highly positive correlation between the content of total phenols and antioxidant activity $(\mathrm{R}=0.936$, $p<0.05)$. Among the red wines, Regent was the wine with the highest antioxidant activity and phenol concentration, whereas the lowest values were noted for Leon Millot. In the white wine group, Jutrzenka was observed to have the highest antioxidant potential and polyphenolic content, 


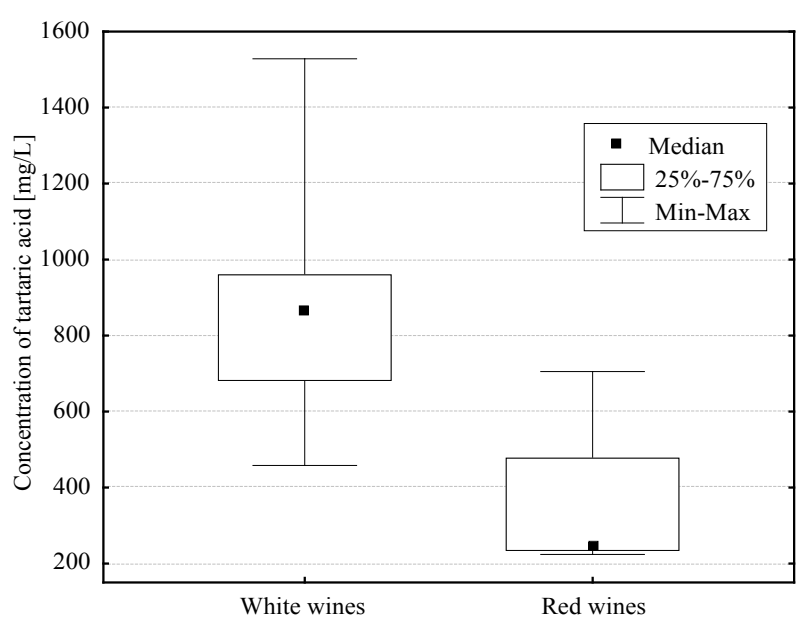

FIGURE 1

Concentration of tartaric acid in white and red wines.

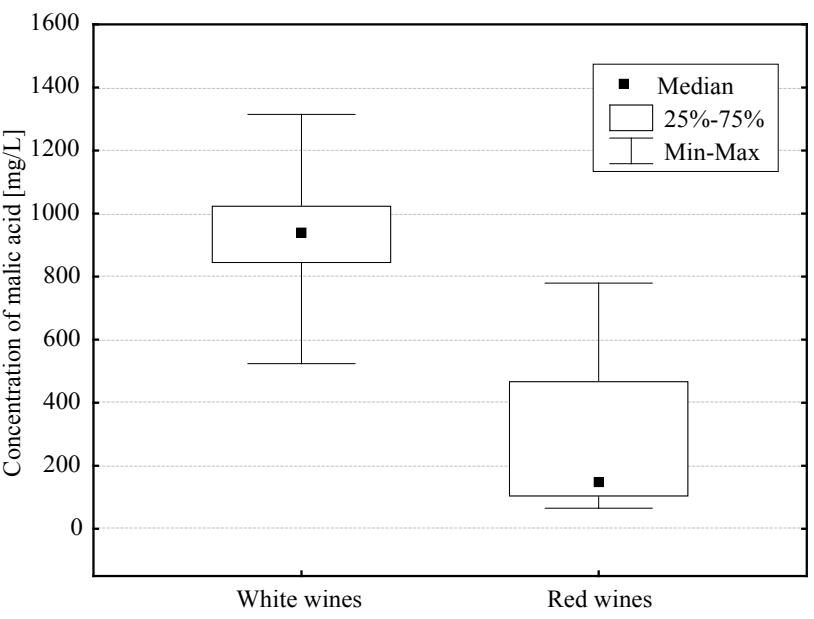

FIGURE 2

Concentration of malic acid in white and red wines.

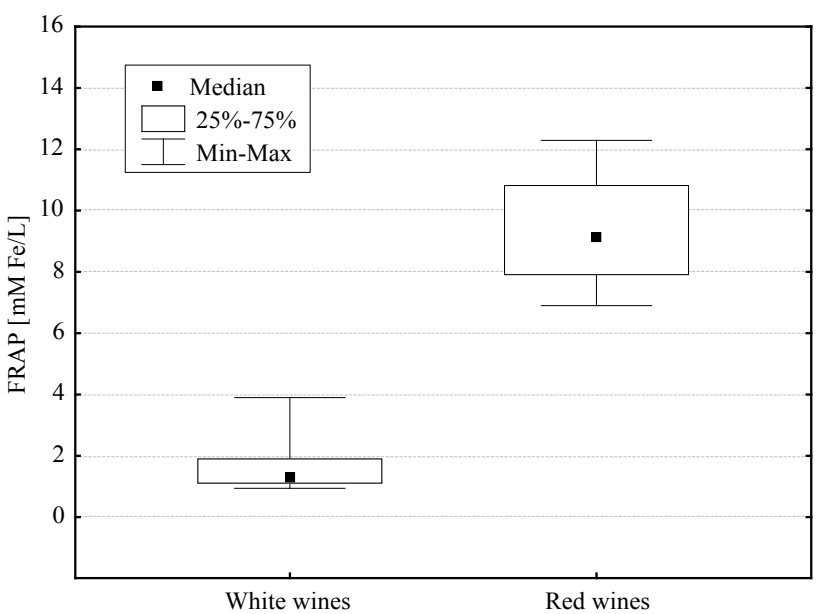

FIGURE 3

Antioxidant activity of white and red wines. while Seyval Blanc had the lowest.

\section{Extract content}

Extract levels in both types of wine were similar. In the white wine it ranged from $9.50 \pm 0.14 \%$ for Seyval Blanc to $12.85 \pm 0.10 \%$ for Jutrzenka. The respective values for the red wine were $9.55 \pm 0.10 \%$ in Maréchal Foch and $12.10 \pm$ $0.15 \%$ in Rondo.

\section{Total acidity as tartaric acid}

Total acidity was found to be significantly higher in the white than in the red wine ( $p=0.04$; Fig. 5). It varied from 2.94 $\pm 0.03 \mathrm{~g} / \mathrm{L}$ (Muscat Odesskij) to $3.96 \pm 0.04 \mathrm{~g} / \mathrm{L}$ (Seyval Blanc), and from $2.76 \pm 0.01 \mathrm{~g} / \mathrm{L}$ (Leon Millot) to $3.07 \pm$ $0.06 \mathrm{~g} / \mathrm{L}$ (Rondo) for the white wine and red wine groups, respectively.

\section{Acidity as pH}

In comparison to the red wine, the white wine displayed significantly lower $\mathrm{pH}(p=0.01$; Fig. 6). The $\mathrm{pH}$ ranged from $3.14 \pm 0.04$ (Sibera) to $3.33 \pm 0.01$ (Aurora) and from $3.43 \pm 0.01$ (Rondo) to $3.61 \pm 0.01$ (Maréchal Foch) for the white and red wine, respectively.

\section{Extract/acidity ratio}

This parameter was higher for the red wine, although the difference was not significant. For the red wine it ranged from $3.24 \pm 0.02{ }^{\circ} \mathrm{B} / \mathrm{g} / \mathrm{L}$ (Maréchal Foch) to $3.98 \pm 0.03{ }^{\circ} \mathrm{B} / \mathrm{g} / \mathrm{L}$ (Leon Millot), while for the white wine it ranged from 2.40 $\pm 0.03{ }^{\circ} \mathrm{B} / \mathrm{g} / \mathrm{L}$ (Seyval Blanc) to $3.54 \pm 0.02^{\circ} \mathrm{B} / \mathrm{g} / \mathrm{L}$ (Bianca).

Cluster analysis of the studied wine brands revealed three clusters (Fig. 7). Cluster 1 included all the white wines with the exception of Jutrzenka. Cluster 2 consisted of Regent and Maréchal Foch, both red wines, with clearly distinct values for parameters, such as the highest levels of FRAP, polyphenols, acetic acid and lactic acid, whereas the levels of malic acid were the lowest. Cluster 3 contained the two remaining red wines and the Jutrzenka white wine, which had a similar biochemical profile. Cluster analysis also revealed some similarities in parameters (Fig. 8). The most highly correlated parameters were (1) total acidity, tartaric acid, malic acid and succinic acid; (2) FRAP, polyphenols and $\mathrm{pH}$ and (3) lactic acid and acetic acid.

\section{Alcohol strength}

The difference between the alcohol strength of the red and white wine was insignificant. In the white wine the alcohol level ranged from $11.58 \pm 0.56 \%$ (Muskat Odesskij) to 13.42 $\pm 0.13 \%$ (Seyval Blanc). The values for the red wine were from $11.14 \pm 0.49 \%$ in Regent to $15.06 \pm 0.81 \%$ in Leon Millot.

\section{DISCUSSION}

At present, chemical analysis is not commonly performed on Polish wines. This could be contributed equally to widely dispersed wine producers and to the scarce opportunities to conduct specialised measurements in field conditions.

We were among the very first researchers to present chemical analysis results for Polish wine produced from various grape cultivars planted near Kraków. The results 
obtained in most cases showed significant differences between red and white wine, which is consistent with the results of other authors (Shellie, 2007; Stratil et al., 2008; Leja et al., 2011). It was also confirmed by the cluster analysis, as all the white wines (apart from Jutrzenka) were classified in a separate cluster. Jutrzenka happened to be classified in the red wine group (with Rondo and Leon Millot), which could be as a result of similar proportions of berry skin (rind, exocarp) to pulp (mesocarp) (Lisek, 2010). Similar concentrations of polyphenols, succinic acid, malic acid and extract was observed in all three wines.

The other examined white wines were much richer in selected organic acids (succinic, malic and tartaric) in comparison to the red wines. This was also confirmed by the total acidity and $\mathrm{pH}$ analysis. The total acidity was lower, while the $\mathrm{pH}$ was higher in the red than in the white wine.

The differences mentioned above can result from discrepancies in winemaking procedures. For the red wines, malolactic fermentation was carried out during vinification. As a result, the red wine showed significantly lower concentrations of malic acids and higher concentrations of succinic and lactic acid. This, in turn, resulted in lower acidity and higher $\mathrm{pH}$ when compared to the white wine. For both the red and white wine, the total acidity appeared too low for cool-climate wine. Still, it should be noted that the sun exposure and the sum of active temperature in the year the grapes were harvested were exceptionally high.

Results reported by other authors show relatively large differences for these parameters within groups of red or white wine (Shellie, 2007; Willershausen et al., 2009; Tarko et al., 2010), although the mean values of the total acidity of white wine are usually higher than for red wine. Moreover, the study carried out on Polish wine by Tarko et al. (2010) yielded similar results to our work. For Jutrzenka and Seyval Blanc, both white wines, a higher total acidity calculated as tartaric acid was found than in any other wine, although our results were slightly lower than those reported by Tarko et al. (2010). The differences may be attributed to the difference in vintage and winemaking procedure. On the other hand, the results obtained in the current research are similar to the observations of other authors concerning the total acidity of different grape cultivars (Ribéreau-Gayon, 2006; Tarko et al., 2008).

Another useful parameter is the extract/acidity ratio. Here, the result for white Seyval Blanc was the lowest $(2.40$ $\pm 0.03{ }^{\circ} \mathrm{B} / \mathrm{g} / \mathrm{L}$ ) and the wine was the most sour in taste. The highest total extract/acidity ratio was observed for Bianca $\left(3.54 \pm 0.02{ }^{\circ} \mathrm{B} / \mathrm{g} / \mathrm{L}\right)$. In general, the investigated red wine displayed a higher, although statistically insignificant, total extract/acidity ratio in comparison to the white wine.

It would be unusual to expect very strict concordance between the results obtained by us and by other authors (Kordiš-Krapež et al., 2001), as many variable conditions, such as climate, grape and soil chemical composition, vineyard location, vintage, agro-technical methods, as well as different winemaking procedures with regard to isolation, maceration, fermentation, etc., play their share in the quality of the final product, which can even differ from batch to batch.

Nonetheless, our results confirmed trends observed

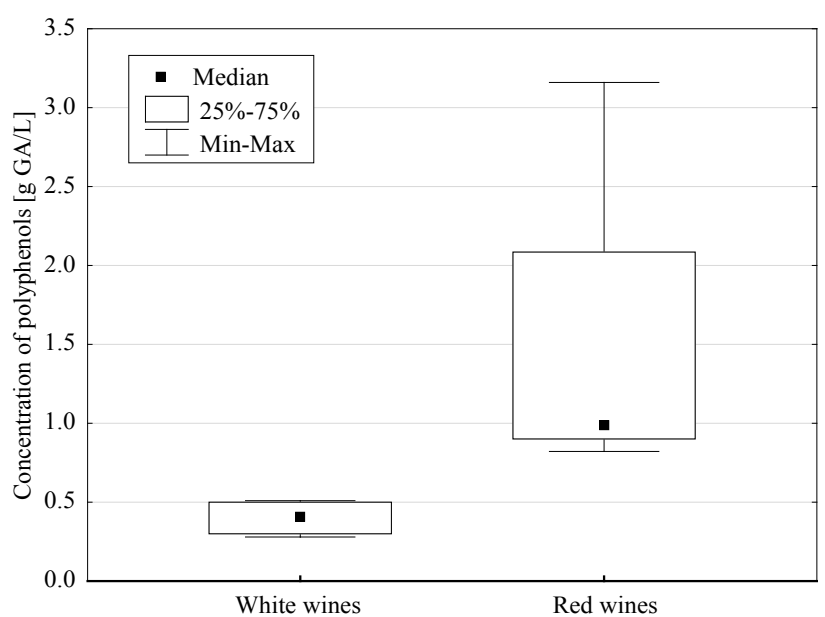

FIGURE 4

Total phenolic content in white and red wines.

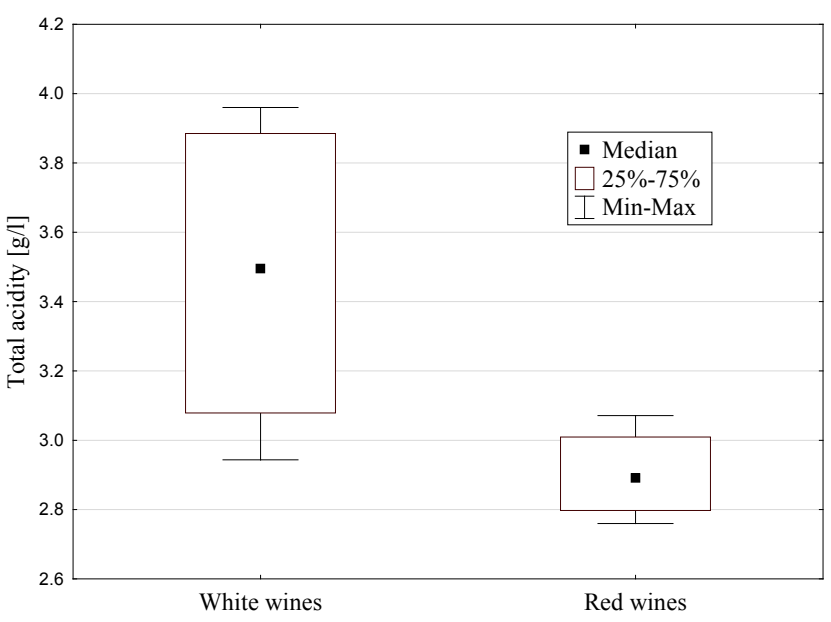

FIGURE 5

Total acidity expressed as tartaric acid in white and red wines.

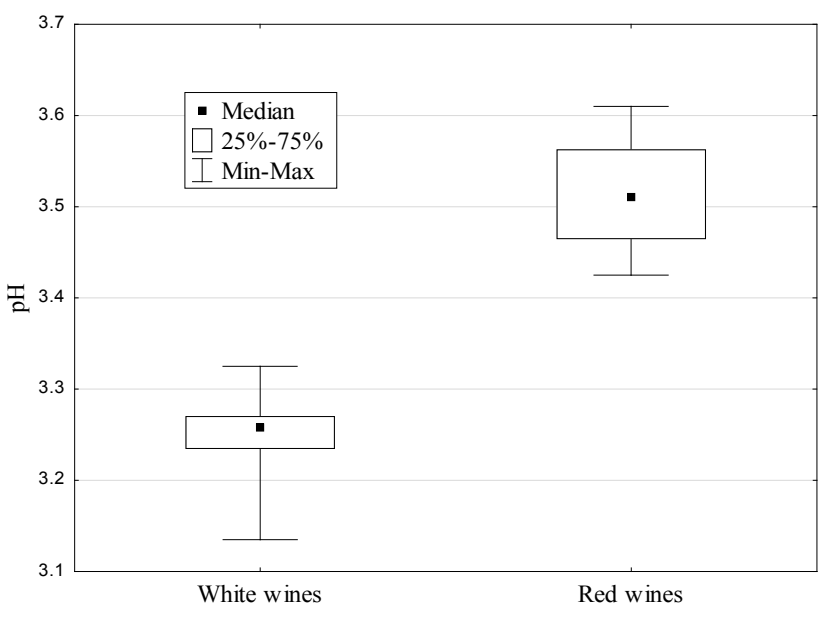

FIGURE 6

Acidity as $\mathrm{pH}$ in white and red wines. 


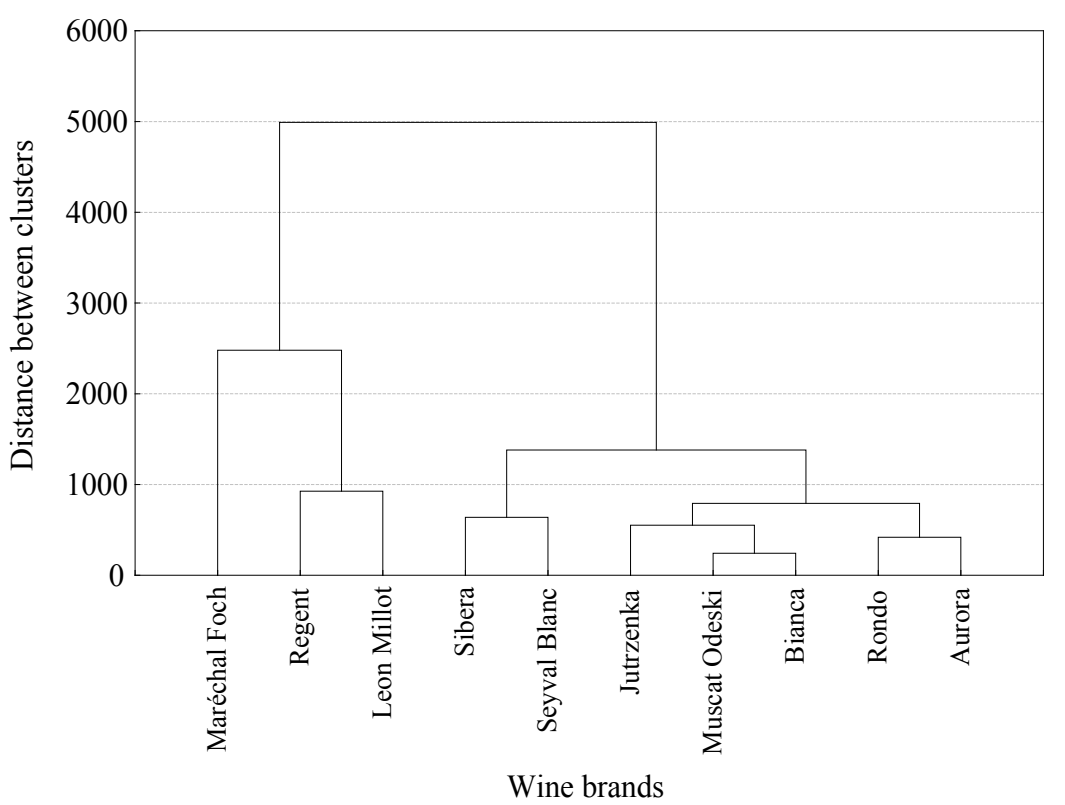

FIGURE 7

Branching-tree diagram for different wine brands.

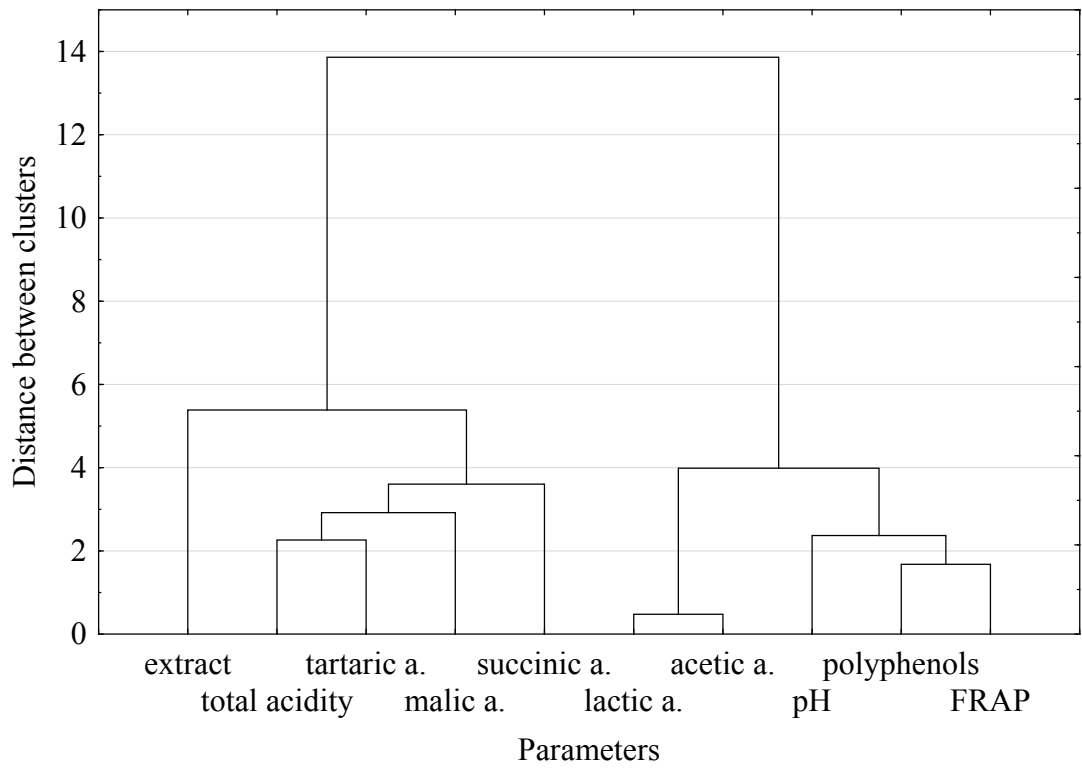

FIGURE 8

Branching-tree diagram for different parameters.

for different grape cultivars. Specifically, the biggest differences were observed in antioxidant parameters, as the concentration of polyphenols and antioxidant activity (FRAP) was observed to be four to five times higher in the red than in the white wine, which is in line with the findings of other authors (Ribéreau-Gayon et al., 2000; Katalinic et al. 2004; Mitić et al., 2010; Tarko et al., 2010). Similarly, a significant correlation was confirmed between polyphenol level and antioxidant activity. Such observations can be explained by the fact that, at the initial production stage of white wine, the grapes are deprived of skin and seeds, which are used for further fermentation (Darias-Martín et al., 2000; Waterhouse, 2002), whereas red wine undergoes a maceration process and only then are the many antioxidant compounds present in the skin and seeds transferred to the solution to be fermented (Pastrana-Bonilla et al., 2003; Szajdek \& Borowska, 2004). Finally, red wines become richer in nearly all antioxidant compounds in comparison to white wines. Among the wines in this study, the ones produced from Jutrzenka grapes showed concentrations of polyphenols and antioxidant activity close to the levels characteristic for red wine. It is important to highlight that wine production from the Jutrzenka grape does not require any agro-chemical pre-treatment, and thus it can be classified as ecological manufacturing.

\section{CONCLUSIONS}

The results obtained show that wines produced under Polish conditions are of a quality comparable to wine from recognised, traditional wine denomination regions. The 
results can also prove useful for further improvements in wine production. Some of the wines, particularly red Regent and white Jutrzenka, displayed high antioxidant activity (FRAP) and polyphenol levels. Specific organic acids and total acidity, as well as FRAP, polyphenols and $\mathrm{pH}$, formed cluster of highly correlated parameters.

\section{LITERATURE CITED}

Aznar, O., Checa, A., Oliver, R., Hernandez-Cassou, S. \& Saurina, J., 2011. Determination of polyphenols in wines by liquid chromatography with UV spectrophotometric detection. J. Separ. Sci. 34, 527-535.

Benzie, I.F. \& Strain, J.J., 1996. The ferric reducing ability of plasma (FRAP) as a measure of antioxidant power: The FRAP assay. Anal Biochem. 15, 70-76.

Darias-Martín, J.J., Rodrígues, O., Díaz, E. \& Lamuela-Raventós, R.M., 2000. Effect of skin contact on the antioxidant phenolics in white wine. Food Chem. 71, 483-487.

Estreicher, S.K., 2004. Wine the past 7,400 years. Available http://www1. mpi-halle.mpg.de/ md_simul/data/special-data/wine-history.pdf [accessed 19/02/2013].

Garrido-Delgado, R., Lopez-Vidal, S., Arce, L. \& Valcarcel, M., 2009. Differentiation and identification of white wine varieties by using electropherogram fingerprints obtained with CE. J. Separ. Sci. 32, 38093816.

Jackson, R.S., 2008 ( $3^{\text {nd }}$ ed). Wine Science, Principles and Applications. Elsevier, USA.

Katalinic, V., Milos, M., Modun, D., Music, I. \& Boban, M., 2004. Antioxidant effectiveness of selected wines in comparison with $(+)$-catechin. Food Chem. 86, 593-600.

Kordiš-Krapež, M., Abram, V., Kač, M. \& Ferjančič, S., 2001. Determination of organic acids in white wines by RP-HPLC. Food Technol. Biotech. 39, 93-99.

Kosmaczewska, J., 2008. Wine tourism in Poland: Prospects of and barriers to development [in Polish]. Studia Periegetica 2(2), 153-159.

Leja, M., Kamińska, I. \& Kulczak, K., 2011. Antioxidative properties in grapes of selected cultivars grown in Poland. Ecol. Chem. Eng. 18, 59-65.

Lisek, J., 2002. Amateur plant cultivation [in Polish]. PZD Publisher, Warsaw.

Lisek, J., 2010. Yielding and healthiness of selected grape cultivars for processing in central Poland. J. Fruit Ornam. Plant Res. 18, 265-272.

Mitić, M.N., Obradović, M.V. \& Pavlović, A.N., 2010. Antioxidant capacities and phenolic levels of different varieties of Serbian white wines. Molecules 15, 2016-2027.

Mulero, J., Zafrilla, P., Cayuela, J.M., Martínes-Cachã, A. \& Pardo, F., 2011. Antioxidant activity and phenolic compounds in organic red wine using different winemaking techniques. J. Food Sci. 76, 436-440.

Myśliwiec R., 2009. Viticulture [in Polish: Uprawa winorośli]. Plantpress, Cracow.

Organisation Internationale de la Vigne et du Vin, n.d. Compendium of international methods of analysis - Method OIV-MA-AS313-01. Total acidity. Available: http://www.oiv.int/oiv/files/6\%20-\%20Domaines\%20 scientifiques/6\%20-\%204\%20Methodes $\% 20 d \% 20$ analyses/6-4-1/EN/OIVMA-AS313-01.pdf [accessed 19/02/2013].
Paśko, P., Bartoń, H., Zagrodzki, P., Groinstein, S., Fołta, M. \& Zachwieja, Z., 2009. Anthocyanins, total polyphenols and antioxidant activity in amaranth and quinoa seeds and sprouts during their growth. Food Chem. $115,994-998$.

Pastrana-Bonilla, E., Akoh, C.C., Sellappan, S. \& Krewer, G., 2003. Phenolic content and antioxidant capacity of muscadine grapes. J. Agr. Food Chem. 51, 5497-5503.

Pellechia, T., 2006. Wine: The 8,000 year-old story of the wine trade. Thunder's Mouth Press, New York.

Ribéreau-Gayon, P., Dubourdieu, D., Donèche, B. \& Lonvaud, A., 2000. Handbook of enology: The microbiology of wine and vinification. Vol. 1. Wiley, New York

Ribéreau-Gayon, P., Glories, Y., Maujean, A. \& Dubourdieu, D., 2006 (2 $2^{\text {nd }}$ ed). Handbook of enology: The chemistry of wine and stabilization and treatments. Vol. 2. John Wiley \& Sons, Ltd. England.

Saito, K. \& Kasai, Z., 1968. Accumulation of tartaric acid in the ripening process of grapes. Plant Cell Physiol. 9, 529-537.

Shellie, K.C., 2007. Viticultural performance of red and white wine grape cultivars in Southwestern Idaho. HortTechnology 17, 595-603.

Silva, B.M., Andrade, P.B., Valentão, P., Ferreres, F., Seabra, R.M. \& Ferreira, M.A., 2004. Quince (Cydonia oblonga Miller) fruit (pulp, peel, and seed) and jam: Antioxidant activity. J. Agr. Food Chem. 52, 4705-4712.

Stratil, P., Kubáń, V. \& Fojtová, J., 2008. Comparison of the phenolic content and total antioxidant activity in wines as determined by spectrophotometric methods. Czech J. Food Sci. 26, 242-253.

Szajdek, A. \& Borowska, J., 2004. Antioxidant properties of food of plant origin [in Polish]. Żywność, Nauka. Technologia. Jakość 4, 5-28.

Tarko, T., Duda-Chodak, A., Sroka, P., Satora, P. \& Jurasz, E., 2008. Physicochemical and antioxidant properties of selected Polish grape and fruit wines. ACTA Sci. Polonor. Technol. Aliment. 7, 35-45.

Tarko, T., Duda-Chodak, A., Sroka, P., Satora, P. \& Jurasz, E., 2010. Polish wines: Characteristics of cool-climate wines. J. Food Compos. Anal. 23, 463-468

Volschenk, H., Van Vuuren, H.J.J. \& Viljoen-Bloom, M., 2006. Malic acid in wine: Origin, function and metabolism during vinification. S. Afr. J. Enol Vitic. 27, 123-136.

Waterhouse, A.L., 2002. Polyphenolic components of wine in alcohol and wine in health and disease. Ann. N. Y. Acad. Sci. 957, 21-36.

Willershausen, B., Callaway, A., Azrak, B., Kloß, Ch. \& Schulz-Dobrick, B., 2009. Prolonged in vitro exposure to white wines enhances the erosive damage on human permanent teeth compared with red wines. Nutr. Res. 8, 558-567.

Winkler, A.J., Cook, J.A., Kliewer, W.M. \& Lider, L.A., 1974. General viticulture. University of California Press, Berkeley.

Yiou, P., García de Cortázar-Atauri, I., Chuine, I., Daux, V., Garnier, E., Viovy, N., Van Leeuwen, C., Parker, A.K. \& Boursiquot, J.-M., 2012. Continental atmospheric circulation over Europe during the Little Ice Age inferred from grape harvest dates. Clim. Past. 8, 577-588. 